\title{
INVESTIGATING TEXT-PROCESSING SKILLS OF EFL STUDENTS: A COMPARISON OF EXPLICIT AND INFERENTIAL COMPREHENSION ITEMS $^{* *}$
}

The aim of this paper is to determine whether reading proficiency is a significant predictor of English as a Foreign Language learners' performance on reading test questions targeting explicit and inferential information when controlling for language proficiency. For this purpose, a total of 38 university students who are taking a course in English as a faculty requirement completed a reading comprehension test with items testing local textual information (locating facts, paraphrasing information, recognizing stated facts) and global textual information (identifying main idea and establishing connections). The participants were first divided into high- and low-proficiency groups based on their scores and then compared by means of a mixed between-within subjects analysis of covariance (ANCOVA). The results indicate that the participants varied in their ability to identify factual information and to make inferences based on stated information with respect to their reading proficiency, and, to a lesser extent, their overall foreign language proficiency, but not as a result of the interaction between these two factors. This finding offers practical support in favour of the Linguistic interdependence hypothesis, which proposes that reading performance in a foreign language is shared to a large degree with reading ability in a first language and with a general reading ability not tied to any specific language.

Key words: reading comprehension, foreign language proficiency, EFL, explicit items, inferential items.

\section{INTRODUCTION}

With the status of English as a lingua franca of tertiary education, the importance of English as a Foreign Language academic reading skills cannot be

\footnotetext{
*jagoda.topalov@ff.uns.ac.rs

* A shorter version of this paper was presented at the 5th International Conference on English Language and Anglophone Literatures Today (ELALT 5) on 11 March 2019.
} 
overstated. There is an increasing need for students to be able to read complex texts in English which place substantial cognitive demands on the reader. Students are required to process both lower level, i.e. literal information from the text, as well as higher level information, drawing conclusions, making predictions and inferences. The aim of this paper is to determine whether English language proficiency and reading proficiency are significant predictors of EFL learners' performance on reading test questions targeting local and global information.

\section{READING COMPREHENSION}

Various reading models have so far been proposed to account for foreign language (FL) reading comprehension, relying mainly on ideas established in L1 reading research. There are several reasons for this reliance. First, a far greater number of studies have been done in the context of L1 reading, primarily with English as the first language, than in the context of reading in a foreign, or even in a second language. Furthermore, practical implications and instructional guidelines derived from the results of empirical research are far more numerous in the context of reading in the first language than in a foreign language. Finally, notable changes in the teaching paradigm and methods of reading instruction stemming from the results of first language reading research have not been sufficiently translated into the context of the foreign language classroom, nor have they been adequately explored. The analysis of the L1 reading process, therefore, makes an indispensable starting point for any exploration of the reading context in a foreign language. Prominent examples of L1 reading models most often used in FL research include the interactive-compensatory model (Stanovich, 1980) and the cognitive processing model of real-life reading comprehension (Khalifa, \& Weir, 2009).

Building on Rumelhart's model (1977), which describes reading as "a pattern [...] synthesized based on information provided simultaneously from several knowledge sources (e.g., feature extraction, orthographic knowledge, lexical knowledge, syntactic knowledge, semantic knowledge" (Stanovich, 1980: 35), Stanovich (1980) proposes the interactive-compensatory model by introducing the notion of compensation. Specifically, Stanovich draws on an earlier psycholinguistic reading model proposed by Coady (1979), who originally introduced the term compensation, stating that "weaknesses in one area can be overcome by strength in another" (Coady, 1979: 11) and explains how top-down processing can compensate for deficiencies in bottom-up language skills. By connecting interaction with compensation in reading, Stanovich explains the mechanisms in the reading process of both good and poor readers. A less successful 
reader who does not understand the meaning of a particular word but is well versed in the subject matter of the text will compensate for inadequate linguistic knowledge by using his or her prior knowledge. On the other hand, a successful reader who is less familiar with the subject matter and content of the text will compensate for any potential comprehension weaknesses by capitalizing on their decoding skills. One of the drawbacks of the interactive-compensatory model lies in the fact that every reader can potentially achieve comprehension in reading by compensating for their weaknesses, so that, although the model is validated by the results of numerous studies, it lacks predictive power (Samuel, \& Kamil, 2002; Urquhart, \& Weir, 1998).

Khalifa and Weir (2009), on the other hand, propose a comprehensive cognitive processing model of reading comprehension, which accounts for real-life reading tasks that are usually tested in reading research and classroom contexts. The model takes into consideration the effects of context variables (including semantic and syntactic characteristics of reading passages, their structure and organization, the purpose of the test), as well as learner characteristics (readers' physiological and psychological states, their reading background) on internal reading processes (Lim, 2017). Internal reading processes include executive processes (lexical access, parsing, inferencing, synthesizing), cognitive resources (linguistic knowledge), and monitoring of established goals and comprehension breakdowns (Lim, 2017). According to the model, reading can take place at the local or global level, and can be either careful or expeditious (Khalifa, \& Weir, 2009). Local comprehension occurs at the "level of decoding (word recognition, lexical access, and syntactic parsing) and establishing propositional meaning" (Khalifa \& Weir, 2009: 45). In contrast, global comprehension includes understanding the main ideas of an entire text and recognizing text structure. Careful reading represents "slow, careful, linear, and incremental reading for comprehension" (Khalifa, \& Weir, 2009: 46), the aim of which is to achieve complete meaning from a given text. It is important to keep in mind, as Lim (2017) points out, that careful reading is the default type of reading that most reading theories and studies tracking eye movement have investigated. "Expeditious reading, however, refers to quick, selective, and efficient reading to locate specific information" (Lim, 2017: 484).

With respect to our understanding of reading processes by means of empirical investigation, the model is particularly valuable as it operationalizes cognitive processing in reading in terms of hierarchically arranged levels of complexity. Tasks requiring lower level cognitive processing include word matching, synonym and word-class matching, grammar/syntax tasks (using 
grammatical knowledge to disambiguate or identify the answer) and propositional meaning (using knowledge of lexis and grammar to understand the meaning of the sentence) (Khalifa, \& Weir, 2009). Tasks which require the activation of higher order cognitive processing include inferencing, building a mental model and understanding text function (text structure and purpose) (Khalifa, \& Weir, 2009). The model further identifies multiple reading comprehension types taking into consideration that the reader may engage fairly different cognitive processes or combinations of processes when reading for different purposes (Kong, 2019). Drawing on work of Carver (1997), Goldman (1997), Enright, Grabe, Koda, Mosenthal, Mulcahy-Ernt, \& Schedl, (2000) and Perfetti (1997), Grabe (2009: 7-9) provides a list of six different purposes of reading which prompt the activation of different reading processes, including reading (1) to search for information, (2) to learn, (3) to integrate information, (4) to evaluate, critique and use information, (5) for quick understanding and (6) for general comprehension. In Khalifa and Weir's (2009) cognitive processing model, metacognitive activities such as goal setting and goal monitoring are crucial in determining the types and levels of reading and, in turn, the relative importance of the associated mental processes (Lim, 2017).

\subsection{Foreign language reading comprehension}

Turning to issues related to reading comprehension in the context of foreign language use, during the 1990s a new research question was formulated concerning the development and acquisition of foreign language reading skills, which resulted in a dual approach to analyzing the reading process: Is foreign language reading a linguistic or a reading issue?

According to the Linguistic threshold hypothesis, reading comprehension breakdowns and low success rates in reading tasks are attributed chiefly to lower levels of linguistic development in the foreign language (Alderson, 1984). If a reader does not possess sufficiently developed skills in processing foreign language vocabulary and syntax, then a heavier cognitive load will be placed on the processes of decoding and syntactic and semantic extraction of meaning, leaving fewer cognitive resources at disposal for higher order processes necessary for a holistic comprehension of the reading passage. "Limited control over the language short circuits the good reader's system causing him/her to revert to poor reader strategies" (Clarke, 1988: 120). The reader must, therefore, reach a certain level of knowledge of a foreign language, in order to be able to read in that language. The hypothesis further introduces the concept of a linguistic threshold, which represents a metaphorical line the reader must cross so as to successfully transfer their skills 
developed by reading texts in the first language to foreign language reading situations. The hypothesis, however, asserts that this transfer does not necessarily take place.

On the other hand, according to the Linguistic interdependence hypothesis, "reading performance in a second language is largely shared with reading ability in a first language" (Bernhardt \& Kamil, 1995: 17). Reading skills developed by reading in the first language can be transferred to reading in a foreign language largely because reading skills are principally connected and essentially equal, so that the reader, having developed a certain reading skill in the first language, does not have to learn the same skill once he or she starts reading in the foreign language. Block (1992: 322) further maintains that, since readers use already acquired skills when they are reading in a foreign language, certain aspects of the reading process are easily transferred from one language to another. This is chiefly possible since reading skills are influenced both by foreign language proficiency and by a general reading skill not connected to any particular language. Namely, foreign language proficiency concerns the lower cognitive processes, such as comprehension of syntactic and semantic information and the formation of the microstructure and the textual model of the text, whereas the independent reading skill has an effect on the formation of the situation model of the text and is active during higher cognitive processes.

Bernhardt (2011) provides an overview of research that has raised the aforementioned research question over the years, examining it in different languages (Spanish, French, English and Turkish, among others) and with participants of different ages (children, adolescents and adult respondents). In most cases, the authors come to a similar conclusion - reading proficiency in the first language, including a general literacy skill not connected to a specific language, are significant predictive factors in the development of reading proficiency in a foreign language, with up to twenty percent of comprehension related to the first language. First language literacy represents a complex set of variables that include different ways in which readers' native languages encode propositions, form the structure of the text, the purpose for which readers read, their attitudes toward reading etc. The reader's level of literacy is of great importance in determining what they will be able to achieve when reading in a foreign language. Readers who have difficulty reading in their first language are likely to have similar difficulties when reading in a foreign language; conversely, any knowledge and reading skills acquired in the first language will not have to be re-acquired when starting to read in a foreign language. Research has further shown that readers' knowledge of a foreign 
language participates with up to thirty percent in the development of reading skills. This includes the knowledge of grammar and vocabulary, similarities and differences between L1 and FL, the value a person attaches to reading, etc. Thus, fifty percent of the process of developing reading skills in a foreign language is explained. Finally, the unexplained variance in the foreign language reading model is hypothesized to include all the individual factors with which the reader interacts with the text, including higher cognitive processes, such as situational model formation, executive control, and strategic processing. The most important contribution of the model is that it reconciles the notion of language threshold versus linguistic interdependence, emphasizing that both language proficiency as well as literacy processes are involved in comprehension (Bernhardt, 2011).

What remains unanswered is how the components of the model proposed by Bernhardt (2011), namely, language proficiency and literacy, interact with different purposes of reading which trigger activation of either lower- or higherlevel cognitive processes, as put forth by Khalifa and Weir (2009). Thus, this paper is aimed at investigating whether proficiency in the English language together with developed reading skills can account for the comprehension of English academic texts at the local and the global level.

\section{METHODOLOGY}

The central question in this study asks whether the participants from two different proficiency groups vary in their performance on reading comprehension items targeting two reading skills, namely (1) identifying factual information and (2) drawing conclusions and making inferences. The set of two null-hypotheses are formulated in the following manner:

H0(1) - Reading Proficiency, English Proficiency and the interaction between these factors do not significantly influence the students' scores on reading comprehension items targeting Explicit/Local information.

H0(2) - Reading Proficiency, English proficiency and the interaction between these factors do not significantly influence the students' scores on reading comprehension items targeting Inferential/Global information.

\subsection{Participants}

A total of 38 students studying at the Faculty of Philosophy, University of Novi Sad who were taking a course in English as a faculty requirement took part in the research reported in this paper. The sample of students included both male 
$(\mathrm{N}=13)$ and female students $(\mathrm{N}=25)$ between the ages of 18 and 22. With respect to the criterion of the year of study, the participants were both first-year $(\mathrm{N}=18)$ and second-year students $(\mathrm{N}=20)$.

Furthermore, all the participants were placed on the B2 level of Common European Framework of Reference for Languages based on the results of the Quick Pen and Paper Test (Oxford University Press/University of Cambridge/Association of Language Testers in Europe, 2001) which they took at the beginning of the academic year.

\subsection{Instrument}

The data was collected by means of TOEFL IBT (ETS, 2009) and Quick Pen and Paper Test (Oxford University Press/University of Cambridge/Association of Language Testers in Europe, 2001). For the purposes of this research, TOEFL IBT included only the reading section of the test, the aim of which was to assess the students' ability to understand academic texts in English (Cohen, \& Upton, 2006: 104-106). Specifically, the section of TOEFL that assesses EFL reading skills is designed to replicate the types of tasks that university students face when reading in an academic context (Jamieson, Jones, Kirsch, Mosenthal, \& Taylor, 1999: 11). In order to gather data regarding the dependent variables, the following two groups of questions were included:

- Local/explicit items - this group included questions that tested the students' ability (1) to locate factual information that was explicitly stated in the text, (2) to distinguish information that was true from information that was not true or not included in the text, and (3) to identify the meanings of individual words or phrases as they are used in the text.

- Global/inferential items - this group included three general types of questions: (1) inference questions, that tested the students' ability to draw conclusions about information that is implied but not explicitly stated in the passage, (2) text insert questions, in which a new sentence was provided and the students were asked to place that sentence into the text where it would best fit, and (3) prose summary questions, which asked students to identify major ideas from the text and distinguish them from minor ideas or from ideas that were not presented in the text.

For each question, the students were required to choose the best answer among four possibilities. The total number of questions targeting Local information 
was eight (with a possible maximum score of 8 ), whereas there were five questions targeting Global information (with a maximum possible score of 5).

\subsection{Variables}

The independent variable in the study was the students' Reading Proficiency operationalized as their achievement on the reading test. The control variable was the students' English Proficiency, indicated by their scores on the placement test.

The dependent variables in the research included Local items (factual and negative factual questions, as well as vocabulary questions) and Global items (inference, insert text and prose summary questions).

\subsection{Procedure}

The research took place at the beginning of the academic year. The students completed the reading section of the TOEFL IBT (ETS, 2009) and the Quick Pen and Paper Test (Oxford University Press/University of Cambridge/Association of Language Testers in Europe, 2001) during a single 90-minute session. For each student, mean scores, medians and standard deviations were computed for both measures. Median scores were then used as a cut-off point between high- and lowproficiency groups for both proficiency measures. The resulting groups were compared by means of a between-subjects analysis of factorial ANOVA. In performing this statistical test, it is possible to answer questions about mean differences between populations as defined by either factor, as well as to ascertain whether the effects of each factor are additive, i.e. whether there is any interaction between the factors (Landau, \& Everitt, 2004). The data were processed using SPSS 20.0 statistical software.

\section{RESULTS}

The results of descriptive tests for both the dependent and the independent variables are given in Table 1.

Table 1: Descriptive statistics

\begin{tabular}{lrrrrr}
\hline & $\begin{array}{c}\text { English } \\
\text { Proficiency }\end{array}$ & $\begin{array}{c}\text { Reading } \\
\text { Proficiency }\end{array}$ & $\begin{array}{c}\text { Explicit } \\
\text { Items }\end{array}$ & Inferential Items \\
\hline Minimum & 29 & 4 & & 1 & 1 \\
\hline
\end{tabular}


INVESTIGATING TEXT-PROCESSING SKILLS OF EFL STUDENTS: ... 171

\begin{tabular}{lcccr}
\hline Maximum & 55 & 12 & 8 & 4 \\
\hline Mean & 40.53 & 9.04 & 5.88 & 3.16 \\
\hline SD & 6.03 & 1.96 & 1.56 & 0.82 \\
\hline Median & 41 & 9 & 6 & 3 \\
\hline Skewness & .017 & -.596 & -.728 & -.628 \\
\hline Std. Error of Skewness & .374 & .383 & .374 & .374 \\
\hline Kurtosis & -.375 & .463 & 1.103 & -.330 \\
\hline Std. Error of Kurtosis & .733 & .750 & .733 & .733 \\
\hline
\end{tabular}

Preliminary results of testing for the normality of distribution indicate that the data is either moderately skewed (values between -1 and $-1 / 2$ or between $+1 / 2$ and +1 ) or approximately symmetric (values between $-1 / 2$ and $+1 / 2$, ) and that the excess kurtosis in the tested variables shows both positive results, indicating more outliers than normality, and negative, indicating fewer outliers. A comparison of these results with the results of their respective standard errors reveals that there are no values that exceed the score higher than three times their respective standard errors, which is considered acceptable in proving normal univariate distribution.

Two factorial ANOVAs were conducted to compare the main effects of Reading Proficiency, English Proficiency and the interaction between Reading Proficiency and English Proficiency on students' performance on Local and Global reading comprehension items, respectively. Both Reading Proficiency and English Proficiency included two levels (high- and low-scorers) (Table 2).

Table 2: Between-subjects factors

\begin{tabular}{lll}
\hline & & $\mathrm{N}$ \\
\hline English Proficiency & Low & 20 \\
\cline { 2 - 3 } & High & 18 \\
\hline Reading Proficiency & Low & 20 \\
\cline { 2 - 3 } & High & 18 \\
\hline
\end{tabular}

A cross-tabulation of mean scores and standard deviations for the students' scores on Local and Global items is shown in Table 3. On Local items, where the highest possible score was 8 , the lowest mean was found with the students 
belonging to both the low-proficiency English subsample and the low-proficiency reading subsample, whereas the highest mean was recorded with the students belonging to both high-proficiency subsamples. On the other hand, with Global items, where the highest possible score was 5 , the lowest score was found with students who were in the high-proficiency language subsample, but in the lowproficiency reading subsample, while the highest recorded mean remained in the same group as with the Local items (high English Proficiency, high Reading Proficiency). Overall, the results indicate that the mean scores on both types of comprehension questions are lower in the low-proficiency reading group.

Table 3: Cross-tabs of mean scores for dependent variables of Local items and Global items

\begin{tabular}{llllll}
\hline \multirow{2}{*}{$\begin{array}{l}\text { Reading } \\
\text { Proficiency }\end{array}$} & $\begin{array}{l}\text { English } \\
\text { Proficiency }\end{array}$ & \multicolumn{2}{c}{ Local items } & \multicolumn{2}{c}{ Global items } \\
\cline { 2 - 6 } \multirow{3}{*}{ Low } & Low & Mean & SD & Mean & \multicolumn{1}{c}{ SD } \\
\cline { 2 - 6 } & High & 4.31 & 1.32 & 2.88 & 0.96 \\
\cline { 2 - 6 } & Total & 5.86 & 0.69 & 2.57 & 0.73 \\
\hline \multirow{3}{*}{ High } & Low & 4.85 & 1.35 & 2.78 & 0.88 \\
\cline { 2 - 6 } & High & 6.86 & 0.69 & 3.29 & 0.70 \\
\hline \multirow{3}{*}{ Total } & Total & 7.18 & 0.98 & 3.73 & 0.41 \\
\cline { 2 - 6 } & Low & 7.06 & 0.87 & 3.56 & 0.57 \\
\cline { 2 - 6 } & High & 5.20 & 1.67 & 3.03 & 0.88 \\
\cline { 2 - 6 } & Total & 6.67 & 1.08 & 3.28 & 0.79 \\
\hline
\end{tabular}

In order to test the significance of the effects of independent variables on the students' reading scores, a two-way analysis of variance was conducted for both of the dependent variables. From the distribution of the participants presented in Table 2, it is clear that the factorial design was unbalanced. Therefore, the Type III option was selected in SPSS as the model for determining the sums of squares, as suggested by some authors as a means of mitigating the potential effects of unbalanced sample sizes (Maxwell, \& Delaney 1990).

The results of between-subjects effects for the dependent variable of Local items yielded a significant main effect for the factor of English Proficiency $(\mathrm{F}(1$, $37)=7.290, \mathrm{p}<.05, \eta_{\mathrm{p}}{ }^{2}=.17$ ), suggesting that students' mean scores on the Explicit 
items vary between high- and low-scorers (Table 4). Furthermore, there was a significant main effect of the factor Reading Proficiency $(F(1,37)=31.150, p<.001$, $\eta_{\mathrm{p}}{ }^{2}=.48$ ), implying that mean scores on Local items also differ significantly between high- and low-scoring participants. We found no statistical evidence of an interaction between Reading Proficiency and English Proficiency; thus, the effect of developed proficiency in the reading skill on the students' scores on items targeting explicit textual information does not vary significantly with more developed knowledge of the English language. The effect sizes for both main effects, reported above as partial eta-squared, are considered large (Cohen, 1988). Fitted ANOVA model is able to explain $61.4 \%$ of the variance in the scores on explicit items. In humanities research, this is generally considered to be a high value, indicating strong relationships between explanatory factors and the results on Local items.

Table 4: Tests of Between-Subjects Effects for Local Items

\begin{tabular}{|c|c|c|c|c|c|c|c|}
\hline Source & $\begin{array}{l}\text { Type III } \\
\text { Sum of } \\
\text { Squares }\end{array}$ & $\mathrm{df}$ & $\begin{array}{l}\text { Mean } \\
\text { Square }\end{array}$ & $\mathrm{F}$ & $\mathrm{p}$ & $\mathrm{y}_{\mathrm{p}}^{2}$ & $\begin{array}{l}\text { Observed } \\
\text { Power }^{\mathrm{b}}\end{array}$ \\
\hline English Proficiency & 7.744 & 1 & 7.744 & 7.290 & .011 & .177 & .746 \\
\hline Reading Proficiency & 33.092 & 1 & 33.092 & 31.150 & .000 & .478 & 1.000 \\
\hline $\begin{array}{l}\text { English Proficiency* } \\
\text { Reading Proficiency }\end{array}$ & 3.307 & 1 & 3.307 & 3.113 & .087 & .084 & .403 \\
\hline Corrected Total & 93.579 & 37 & & & & & \\
\hline \multicolumn{8}{|c|}{ a. $\mathrm{R}^{2}=.614$ (Adjusted $\mathrm{R}^{2}=.580$ ) } \\
\hline b. Computed using all & & & & & & & \\
\hline
\end{tabular}

Further pairwise comparisons reveal that the students from the highproficiency reading group are estimated to score 1.937 points higher than the low proficiency group (95\% CI from 1.232 to 2.642 points).

The results of the influence of the two independent variables (Reading Proficiency and English Proficiency) on the students' scores on Global items (see Table 5) reveal a statistically significant effect at the .01 significance level only for Reading Proficiency; the main effect yielded an $F$ ratio of $F(1,37)=9.614, p<.01$, $\eta_{\mathrm{p}}{ }^{2}=.22$, indicating a significant difference between low-scorers $(\mathrm{M}=2.73, \mathrm{SD}=.17)$ and high-scorers $(\mathrm{M}=3.51, \mathrm{SD}=.18)$. The effect size, reported as partial eta-squared, is considered large (Cohen, 1988).

Table 5: Tests of Between-Subjects Effects for Global Items 


\begin{tabular}{lrrrrrrrr}
\hline Source & $\begin{array}{c}\text { Type III } \\
\text { Sum of } \\
\text { Squares }\end{array}$ & df & $\begin{array}{c}\text { Mean } \\
\text { Square }\end{array}$ & F & p & $\mathrm{y}_{\mathrm{p}}{ }^{2}$ & $\begin{array}{c}\text { Observed } \\
\text { Power }^{\mathrm{b}}\end{array}$ \\
\hline English Proficiency & .036 & 1 & .036 & .065 & .800 & .002 & .057 \\
\hline Reading Proficiency & 5.345 & 1 & 5.345 & 9.614 & .004 & .220 & .854 \\
\hline $\begin{array}{l}\text { English Proficiency } * \\
\text { Reading Proficiency }\end{array}$ & 1.256 & 1 & 1.256 & 2.259 & .142 & .062 & .309 \\
\hline Corrected Total & 25.954 & 37 & & & & & \\
\hline a. $\mathrm{R}^{2}=.272$ (Adjusted $\mathrm{R}^{2}=.207$ ) & & & & & & \\
\hline b. Computed using alpha $=.05$ & & & & & & \\
\hline
\end{tabular}

Further pairwise comparisons reveal that students from the high-proficiency reading group are estimated to score on average .778 points higher than the lowproficiency group (95\% CI from .268 to 1.289). Neither the main effect for English Proficiency $(\mathrm{F}(1,37)=.065$, p $>.05)$, nor the interaction effect $(\mathrm{F}(1,37)=1.256$, p>.05) were significant. Fitted ANOVA model is able to explain 27.2\% of the variance in the score on the inferential items.

\section{DISCUSSION}

The aim of this paper was to explore the relative effects of two factors that have so far been found to be important in achieving reading comprehension in the foreign language, namely language proficiency and literacy, on the students' ability to answer comprehension questions that targeted local information, i.e. information that was explicitly stated in the text, and global information, i.e. information which required readers to draw conclusions, make inferences and create an accurate situational model of the text as a whole.

Overall, students varied in their ability to answer both explicit and inferential questions, with higher success rates found for explicit items regardless of the students' proficiency levels. The least successful in answering explicit questions were students who were both in low-proficiency EFL subsample and lowproficiency literacy subsample, whereas the highest scores were recorded with the students belonging to both high-proficiency subsamples, which was a result that was expected. One unexpected finding was related to the least successful subsample in answering global questions. What is curious is that the students who were in the 
low literacy group, but high language proficiency group scored the lowest, a finding that will be discussed further on in the text.

Concerning the results of the effects of the two investigated factors on the students scores on explicit items, it is clear that the students varied in their ability to answer questions based on both proficiency levels. The results indicate that tasks which required readers to identify stated facts and recognize important details that are explicitly stated in the text and, by means of various stylistic devices, marked as important are directly connected with both the reader's knowledge of the foreign language and the level of the development of their reading skills. Overall, the students from the low-proficiency reading group were less successful than the highproficiency reading group regardless of the language proficiency level, further confirmed by a larger effect size of this factor, when compared to the language proficiency variable. This finding would also suggest that, even though the students' knowledge of a foreign language plays a role in correctly answering questions which target information that is explicitly stated in the text, or that focuses on understanding the meanings of words and phrases, general reading skills were found to be more influential. This is also only a partial confirmation of the relative contribution of each factor in Bernardt's (2011) hypothesized model of foreign language reading comprehension, according to which it is foreign language proficiency that accounts for a greater amount of variation in reading skill than literacy.

Turning to the results investigating students' scores on global questions, it was revealed that the only significant effect can be attributed to reading proficiency, with high-proficiency reading subsample significantly outscoring the lowproficiency reading subsample. No effects were found for English language proficiency or the interaction between the two factors. For a possible interpretation of this result we should turn back to Khalifa and Weir's (2009) cognitive processing model of reading comprehension and its hierarchically organized cognitive mechanisms active while reading. Namely, in order to correctly answer global tasks, readers must activate higher-order cognitive processes, including drawing accurate inferences from implicit textual information and understanding text structure and purpose. While a more highly developed linguistic knowledge would certainly not be a disadvantage in achieving a holistic understanding of the text, the results reveal that it is not language proficiency, but literacy that is crucial in creating appropriate mental representations of the text. Good readers are sensitive to the organizational structure connected with different types of texts or to stylistic and rhetorical cues, such as cohesive elements; in other words, good readers are able to 
compensate linguistic deficiencies while reading a text in a foreign language by drawing on their previous knowledge and reading experiences in order to build accurate text and/or situational models of reader interpretation and undertake executive control (Grabe, 2009). On the other hand, poor readers, who fail to accurately interpret global cues in reading passages, are not able to compensate for the weaknesses in their reading skills by developed linguistic knowledge, thus failing to activate higher cognitive processes and to provide accurate answers to global questions. This interpretation also offers a possible explanation of the unexpected result mentioned above, according to which high-proficiency, lowreading subgroup scored the lowest.

On the whole, the lower-proficiency reading group had more difficulty answering questions that required a holistic understanding of the text regardless of their level of English language proficiency, suggesting that low-level readers process text using bottom-up strategies. This finding offers practical support in favour of the Linguistic interdependence hypothesis, which proposes that reading performance in a foreign language is to a large degree dependent on a general reading ability not connected to any particular language. Other studies have come to a similar conclusion, pointing out that readers who read in a foreign language find it easier to make local connections in texts (Becker, 2016; Hansen, \& Jensen, 1994; Shohamy, \& Inbar, 1991) as opposed to readers who read in their first language, and often have difficulty recognizing cohesion signals, such as linking devices and anaphores (Carrell, 1988; Devine, 1988; Mackay, 1979).

\section{CONCLUSION}

The research reported in this paper looked into issues concerning the influence of different types of knowledge, i.e. foreign language proficiency and literacy, on the success EFL readers achieve when answering comprehension questions which target information that is explicitly or implicitly stated in the text. The results indicated that the readers varied in their ability to identify factual information and to make inferences based on stated information with respect to their reading proficiency, and, to a lesser extent, their overall foreign language proficiency, but not as a result of the interaction of these two factors. An important conclusion also concerns the issue of compensation, as proposed by Stanovich (1980) and adopted by Bernhardt (2011) for foreign language reading contexts. Namely, the results revealed that, when dealing with global comprehension tasks, good readers were able to compensate for their linguistic deficiencies by relying on their developed reading skills, but poor readers were not able to compensate for 
their less developed reading abilities by relying on their developed linguistic knowledge.

The limitations of the study reported in the paper are numerous. Apart from the threats that commonly apply in this type of research, including subjects effects (students not having optimal level of motivation to complete the proficiency tests, and/or feeling the effects of their current physiological states), as well as test bias, in terms of the topic of the text which may be more familiar to some students and less to others, the main limitation concerns the EFL level of the participants. It is quite possible that lower levels, especially the beginning level, would provide a confirmation of the Linguistic threshold hypothesis. This limitation is due to practical reasons, as the students at this level were the only ones who took a standardized reading comprehension test as part of their syllabus, so that the organization and implementation of data collection interfered the least with their lessons. This limitation is, hopefully, mitigated by the fact that a standardized reading comprehension test such as TOEFL IBT takes into account the testee's language level and creates the reading tasks that are adapted to higher linguistic demands which the learners are expected to meet at B2 level.

Despite the limitations, a potential contribution of the study may be best recognized in the practical implications that follow from its results. Most importantly, the research has shown that the reading skill is not solely tied to language proficiency. Students can overcome language problems by employing compensatory reading strategies, such as elaboration, world-knowledge, making inferences, all of which can be taught. In light of this, the paper ends with a recommendation for EFL teachers to explicitly work on students' metacognitive awareness and strategic competence.

Jagoda P. Topalov

ISTRAŽIVANJE VEŠTINE ANALIZE TEKSTA NA ENGLESKOM KAO STRANOM: POREĐENJE EKSPLICITNIH I IMPLICITNIH ZADATAKA

\section{Rezime}

Ovaj rad ima za cilj da ponudi odgovor na pitanje da li, ukoliko kao faktor kontrolišemo znanje engleskog jezika, nivo razvoja veštine čitanja predstavlja značajan prediktor uspeha koji studenti koji uče engleski jezik kao strani postižu prilikom rešavanja zadataka na testu razumevanja teksta koji su usmereni na lokalne, odnosno eksplicitno navedene informacije, $\mathrm{s}$ jedne strane, i globalne, odnosno informacije koje zahtevaju izvođenje zaključaka i razumevanje celovitosti teksta, njegove strukture i svrhe, s druge? U tu svrhu, ukupno 38 
studenata koji pohađaju nastavu engleskog jezika kao izbornog predmeta na Filozofskom fakultetu u Novom Sadu uradilo je test razumevanja teksta koji se sastojao od pitanja koji testiraju lokalne tekstualne informacije (lociranje činjenica, parafraziranje informacija, prepoznavanje navedenih činjenica) i globalne tekstualne informacije (identifikovanje glavnih ideja i uspostavljanje referentnih veza). Učesnici su prvo podeljeni na uspešne i manje uspešne čitaoce na osnovu rezultata testiranja, a zatim su upoređeni pomoću analize kovarijanse (ANCOVA). Rezultati pokazuju da se učesnici razlikuju u sposobnosti identifikovanja činjenične informacije i izvođenja zaključaka na osnovu navedenih informacija spram nivoa razvoja veštine čitanja, a u manjoj meri i spram nivoa poznavanja stranog jezika, ali ne i kao rezultat interakcije između ova dva faktora. Ovaj rezultat nudi praktičnu podršku u korist hipoteze jezičke međuzavisnosti, koja predlaže da je čitanje na stranom jeziku u velikoj meri povezano sa veštinom čitanja na maternjem jeziku i sa nezavisnom veštinom čitanja koja nije vezana za neki određeni jezik. Pored toga, studenti sa slabijim nivoom znanja jezika i nedovoljno razvijenom veštinom čitanja imali su više poteškoća pri rešavanju zadataka koja su zahtevala holističko razumevanje teksta, što navodi na zaključak da ovi čitaoci obrađuju tekst koristeći strategije odozdo prema gore.

Ključne reči: razumevanje teksta, znanje stranog jezika, engleski kao strani, eksplicitne informacije, implicitne informacije.

\section{REFERENCES}

Alderson, J. (1984). Reading in a foreign language: A reading problem or a language problem? In: Alderson, J. \& Urquhart, A. (eds.) (1984). Reading in a Foreign Language. London: Longman. 1-24

Becker, A. (2016). L2 students' performance on listening comprehension items targeting local and global information. Journal of English for Academic Purposes, 24, 1-13.

Bernhardt, E. (2011). Understanding advanced second language reading. New York: Routledge.

Bernhardt, E. \& Kamil, M. (1995). Interpreting relationships between L1 and L2 reading: Consolidating the Linguistic Threshold and the Linguistic Interdependence Hypotheses. Applied Linguistics, 16, 15-34.

Block, E. (1992). See how they read: Comprehension monitoring of L1 and L2 readers. TESOL Quarterly, 26, 319-342.

Carrell, P. (1988). Some causes of text-boundedness and schema interference in ESL reading classrooms. In: Carell, P.-Devine, J. \& Eskey, D. (eds.) (1988). Interactive Approaches to Second Language Reading. Cambridge: Cambridge University Press. 239-259. 
Carver, R. (1997). Reading for one second, one minute, or one year from the perspective of reading theory. Scientific Studies of Reading, 1(1), 3-43.

Clarke, M. (1988). The short circuit hypothesis of ESL reading - or when language competence interferes with reading performance. In: Carrel, P.-Devine, J. \& Eskey, D. (eds.) (1988). Interactive approaches to second language reading. Cambridge: Cambridge University Press. 114-124.

Coady, J. (1979). A psycholinguistic model of the ESL reader. In: Mackay, R.Barkman, B. \& Jordan, R. (eds.) (1979). Reading in a Second Language. Rowley, MA: Newbury House. 5-12.

Cohen, A. \& Upton, T. (2006). Strategies in responding to the new TOEFL reading tasks (TOEFL Monograph No. MS-33). ETS: Princeton, NJ

Cohen, J. (1988). Statistical power analysis for the behavioral sciences $\left(2^{\text {nd }}\right.$ Edition). Hillsdale, NJ: Lawrence Erlbaum Associates, Publishers.

Devine, J. (1988). The relationship between general language competence and second language reading proficiency: Implications for teaching. In: Carrell, P. L.-Devine, J. \& Eskey, D. (eds.) (1988). Interactive approaches to second language reading. New York: Cambridge University Press. 261277.

Enright, M.-Grabe, W.-Koda, K.-Mosenthal, P.-Mulcahy-Ernt, P. \& Schedl, M. (2000). TOEFL 2000 reading framework: A working paper (TOEFL Monograph Series Report No. 17). Princeton: Educational Testing Service.

ETS - Educational Testing Service. (2009). The official guide to TOEFL® Test. New York: McGraw-Hill.

Goldman, S. R. (1997). Learning from text: Reflections on the past and suggestions for the future. Discourse Processes, 23/3, 357-398.

Grabe, W. (2009). Reading in a second language: Moving from theory to practice. Cambridge: Cambridge University Press.

Hansen, C., \& Jensen, C. (1994). Evaluating lecture comprehension. In: Flowerdew, J. (ed.) (1994) Academic listening. New York: Cambridge University Press. 241-268.

Jamieson, J.-Jones, S.-Kirsch, I.-Mosenthal, P. \& Taylor, C. (1999). TOEFL 2000 framework: A working paper (TOEFL Monograph No. MS-16). Princeton, NJ: ETS.

Khalifa, H., \& Weir, C. J. (2009). Examining reading: Research and practice in assessing second language reading. Cambridge: Cambridge University Press. 
Kong, J. (2019). Investigating the role of test methods in testing reading comprehension. Singapore: Springer.

Landau, S. \& Everitt, B. (2004). A handbook of statistical analyses using SPSS. New York: Chapman \& Hall/CRC.

Lim, H. J. (2017). Exploring test takers' cognition in a high-stakes reading test: An eye-tracking study. The Journal of Asia TEFL, 14/3, 482-500.

Mackay, R. (1979). Teaching the information-gathering skills. In: Mackay, R.Barkman, B. \& Jordan, R. (eds.) (1979). Reading in a second language. Rowley, MA: Newbury House. 79-90.

Maxwell, S. \& Delaney, H. (1990). Designing experiments and analyzing data. Stamford, CT: Wadsworth.

Oxford University Press/University of Cambridge/Association of Language Testers in Europe (2001). Quick placement test: Paper and pen test. Oxford: Oxford University Press.

Perfetti, C. A. (1997). Sentences, individual differences, and multiple texts: Three issues in text comprehension. Discourse Processes, 23/3, 337-355.

Rumelhart, D. (1977). Toward an interactive model of reading. In: Dornic, S. (ed.) (1977). Attention and Performance. Hillsdale, NJ: Erlbaum. 573-603.

Samuel, J. \& Kamil, M. (2002). Models of the reading process. In: Pearson, D. (ed.) (2002). Handbook of Reading Research, Volume 1. Mahwah, NJ: Lawrence Erlbaum. 185-224.

Shohamy, E., \& Inbar, O. (1991). Validation of listening comprehension tests: The effect of text and question type. Language Testing, 8, 23-40.

Stanovich, K. (1980). Toward an interactive-compensatory model of individual differences in the acquisition of literacy. Reading Research Quarterly, 16/1, 32-71.

Urquhart, A., \& Weir, C. (1998). Reading in a second language: Process, product and practice. New York: Longman. 